\title{
Is Swine-origin Influenza a Predisposing Factor for Deep Vein Thrombosis?
}

\section{Domuz Gribi Derin Ven Trombozu için Predispozan bir Faktör müdür?}

\author{
Müge Gökçe ${ }^{1}$, Şule Ünal ${ }^{1}$, Selin Aytaç${ }^{1}$, Ateş Kara², Mehmet Ceyhan², Murat Tuncer ${ }^{1}$, \\ Fatma Gümrük ${ }^{1}$ \\ ${ }^{1}$ Hacettepe University, School of Medicine, Department of Pediatric Hematology, Ankara, Turkey \\ ${ }^{2}$ Hacettepe University, School of Medicine, Department of Pediatric Infectious Disease, Ankara, Turkey
}

\begin{abstract}
Herein we report a sixteen-year-old female that developed deep vein thrombosis (DVT) while undergoing treatment for H1N1 pneumonia. To the best of our knowledge this is the first report of H1N1/09 infection complicated by DVT in an adolescent patient with no detected risk factors other than immobilization. Healthcare providers should be aware of the possibility of thrombosis in patients with swine-origin influenza, especially in those with additional risk factors.
\end{abstract}

Key Words: Children, Deep venous thrombosis, Swine-origin (pandemic) influenza

Özet

Burada HIN1 enfeksiyonu için tedavi alırken, derin ven trombozu geliştiren bir olguyu sunmaktayız. Mevcut bilgilerimize gore; HINl enfeksiyonu sırasında - immobilizasyon dışında başka hiçbir risk faktörü olmayan - bir adölesanda tromboz gelişimi ilk defa bildirilmektedir. Domuz gribi pandemilerinde özellikle eşlik eden risk faktörleri olanlarda tromboz gelişebileceği akılda tutulmalıdır.

Anahtar Sözcükler: Çocukluk çağı, Derin ven trombozu, Domuz gribi, HıN1 pandemi

\section{Introduction}

Venous thromboembolism (VTE) is a multifactorial entity that arises due to variable interactions between genetic and environmental components, with an incidence among children of 0.07-0.14/10,000 [1]. The incidence of VTE in hospitalized children has been reported to be as high as 58 cases per 10,000 hospital admissions [2]. The majority of children with VTE have comorbid medical conditions. Infection, dehydration, trauma, cancer, central venous catheterization, and chemotherapy are the most common predisposing factors for the development of thrombosis in children [3]. We reported earlier that thrombosis was associated with infection in $68 \%$ of hospitalized children with thrombosis [4].
Since April 2009, H1N1 infection has been a major concern, as it has spread rapidly worldwide. Herein, we report a sixteen-year-old female that developed thrombosis in the deep femoral vein while undergoing treatment for $\mathrm{H} 1 \mathrm{~N} 1$ pneumonia.

\section{Case}

A sixteen-year-old female was admitted to the hospital due to fever $\left(41^{\circ} \mathrm{C}\right)$, difficulty breathing, and perioral cyanosis. She had been prescribed oseltamivir phosphate (Tamiflu) for pandemic influenza A. She has cerebral palsy due to periventricular leukomalacia as a complication of premature birth, and had undergone surgery for developmental dysplasia of the left hip without thrombotic com-

Address for Correspondence: Müge GÖKÇE, M.D.,

Hacettepe Üniversitesi, Hacettepe Tip Fakültesi, Çocuk Hematoloji Bilim Dalı, Ankara, Turkey

Phone: +90 3123051170 E-mail: muge.gokce@hacettepe.edu.tr

Received/Geliş tarihi : July 23, 2010

Accepted/Kabul tarihi : November 22, 2010 
plication at age 3 years. Written informed consent was obtained from the patient.

Physical examination showed tachypnea, dyspnea, and perioral cyanosis. Oxygen saturation was $57 \%$ based on pulse oximetry. Bilateral inspiratory crackles were present on auscultation. Because of her neurological condition, the arms were fully flexed, whereas her legs were extended, with no apparent difference in diameters. Deep tendon reflexes were hyperactive, the plantar response was extensor, and the remainder of the physical examination was unremarkable.

Arterial blood gas analysis indicated respiratory acidosis based on the following results: $\mathrm{pH}: 7.08 ; \mathrm{pCO}_{2}: 59.8$ mmHg; $\mathrm{pO}_{2}$ : $61.9 \mathrm{mmHg}$. Complete blood count was as follows: hemoglobin: $10 \mathrm{~g} \mathrm{dL}^{-1}$; hematocrit: $31.2 \%$; WBC count: $8.3 \times 10^{9} \mathrm{~L}^{-1}$; thrombocyte count: $318 \times 10^{9} \mathrm{~L}^{-1}$. Liver and kidney function test results were within normal limits. Chest X-ray showed bilateral reticular infiltration. Nasopharyngeal swab for pandemic influenza was taken. Oral clarithromycin and parenteral clindamycin were added to her treatment. With oxygen support and bronchodilation treatment, the hypoxemia subsided. Polymerase chain reaction analysis for influenza virus H1N1 was positive [5]. The patient did not require mechanical ventilation support and her respiratory status improved during the next few days.

On the fifth day of the treatment her left leg appeared to be swollen and larger in diameter than the right leg. Doppler ultrasonography showed a hyperechogenic thrombus with non-compressibility in the left deep femoral vein. Enoxaparin $1 \mathrm{mg} \mathrm{kg}^{-1}$ b.i.d. was initiated and detailed prothrombotic risk factor analysis was performed. Basal activated partial thromboplastin time (aPTT) and international normalized ratio (INR) were within normal limits. The plasma fibrinogen level was $436 \mathrm{mg} \mathrm{dL}^{-1}$ (normal range: $200-450 \mathrm{mg} \mathrm{dL}^{-1}$ ) and thrombin time was $14 \mathrm{~s}$ (normal range: 12-16 s). D-dimer was $5.42 \mu \mathrm{g} \mathrm{m}^{-1}$ (normal range: $0-0.48 \mu \mathrm{g} \mathrm{mL}{ }^{-1}$ ), anti-thrombin III activity was $101 \%$ (normal range: $80 \%-120 \%$ ), plasma protein C and protein S levels were 84\% (normal range: 70\%-130\%) and 92\% (normal range:60\%-130\%), respectively, and the plasma factor VIII level was 126\% (normal range: 53\%170\%). Anticardiolipin and antiphospholipid antibodies were negative. The serum lipid profile, and lipoprotein-a and homocysteine levels were normal. Analysis for methylenetetrahydrofolate reductase (MTHFR C677T -/-), factor V Leiden, and prothrombin 20210A mutations were negative. Echocardiographic evaluation showed normal systolic and diastolic functions without intracardiac throm- bus. Thoracic CT performed to investigate an associated pulmonary thromboembolism (PTE) was unremarkable. Swelling in the patient's left leg regressed by the 3rd day of enoxaparin treatment, and she was discharged $10 \mathrm{~d}$ after admission with a therapeutic antiXa level.

\section{Discussion}

The pathophysiology of thrombosis is based on the presence of 3 factors: endothelial injury, hypercoagulability, and venous stasis. Damage to vessel walls prevents endothelium from inhibiting coagulation and initiating local fibrinolysis. As VTE is usually multifactorial in childhood, detailed analysis should be performed in an effort to determine the underlying etiology.

In addition to coagulation cascade activation, inflammatory response plays a role in thrombus formation via production of microparticles (MPs) that carry cell-specific molecules-proteins such as galectins [6]. Stimulation of monocytes, especially by galectin-1, leads to cell activation and tissue factor expression that triggers the coagulation pathway. Furthermore, oxygen free radicals produced during inflammation are known to induce thrombosis in microvessels via activation of platelet aggregation [7]. Infectious agents, including bacteria, viruses, and parasites, may initiate this process. A 13-year-old male that developed deep vein thrombosis (DVT) and pulmonary embolism following pneumonia caused by Mycoplasma pneumoniae was reported; however, protein S deficiency and transient lupus anticoagulant were underlying risk factors [8]. It is also known that varicella zoster infection can cause thrombosis in patients with protein $\mathrm{S}$ and $\mathrm{C}$ deficiency [9]. An 8-year-old boy that developed middle cerebral artery thrombosis as a result of Streptococcus oralis infection was reported [10].

Since being identified in Mexico City in April 2009, pandemic influenza A (H1N1) has become a significant cause of morbidity and mortality worldwide. Till 6 December 2009, 208 countries have reported laboratory-confirmed cases of pandemic influenza H1N1 to the World Health Organization (WHO) [11]. Although hospitalized children with swine-origin influenza infection are more likely to have underlying medical conditions, healthy individuals are also at risk $\mathrm{f} \mathrm{HlNl}$ infection and infection-related death. Unusual clinical presentations of H1N1 infection reported to date have included parotitis, conjunctivitis, and extensive bowel involvement with mesenteric thrombosis and hemophagocytic syndrome $[12,13]$

The presented case developed DVT while undergoing treatment for $\mathrm{H} 1 \mathrm{Nl}$ pneumonia. The patient did not 
have any coagulation abnormality or prothrombotic risk factor other than immobilization. The patient's history of thrombotic episodes was negative despite having cerebral palsy and having undergone surgery for hip dysplasia. The patient's family history of thrombosis was also negative. Detailed thrombotic risk factor analysis was performed to clarify the association between swine flu and DVT. H1N1 infection in the presented case might have triggered the formation of thrombosis because of endothelial injury in the left deep femoral vein due to previous surgery. D-dimer elevation indicated acute thrombosis. $\mathrm{H}$ a r m s et al. performed autopsy on 8 patients with H1Nl infection and reported that 5 had peripheral pulmonary vascular thrombosis and all 8 had cytophagocytosis [14]. An in vitro study reported that monocytes and endothelial cells that were incubated with influenza were able to activate coagulation via endothelial dysfunction and elevated tissue factor levels $[15,16]$. It is known that seasonal flu vaccine reduces the risk of cardiovascular events in patients with coronary heart disease. A novel study reported that influenza vaccination is associated with a reduced risk of VTE, whereas influenza infection itself may predispose individuals to thrombus formation, especially DVT [17].

In conclusion, thrombotic events should be considered among the possible complications of H1Nl infection, and low molecular weight heparin prophylaxis might be considered in immobilized patients with HlN1 infection.

\section{Acknowledgements}

Each author contributed to this report equally.

\section{Conflict of Interest Statement}

The authors of this paper have no conflicts of interest, including specific financial interests, relationships, and/ or affiliations relevant to the subject matter or materials included.

\section{References}

1. Goldenberg NA, Bernard TJ: Venous thromboembolism in children. Hematol Oncol Clin North Am 2010; 24: 151-166

2. Raffini L, Huang YS, Witmer C, Feudtner C: Dramatic increase in venous thromboembolism in children's hospital in the United States from 2001 to 2007. Pediatrics 2009; 124: 1001-1008

3. Raffini L: Thrombophilia in children: Who to test, how, when and why? Hematology. Am Soc Hematol Educ Program 2008; 228-235

4. Gurgey A, Aslan D: Outcome of noncatheter-related thrombosis in children: Influence of underlying or coexisting factors. J Pediatr Hematol Oncol 2001; 23: 159-164
5. Song MK, Chang J, Hong Y, Hong S, Kim SW: Direct multiplex reverse transcription-nested PCR detection of influenza viruses without RNA purification. J Microbiol Biotechnol 2009; 19: 1470-1474

6. Diaz JA, Ramacciotti E, Wakefield TW: Do galectins play a role in venous thrombosis? A review. Thromb Res 2010; 125: $373-376$

7. Jourdan A, Aguejouf $O$, Imbault P, Doutremepuich F, Inamo J, Doutremepuich C: Experimental thrombosis model induced by free radicals. Application to aspirin and other different substances. Thromb Res 1995; 79: 109-123

8. Graw-Panzer KD, Verma S, Rao S, Miller ST, Lee H: Venous thrombosis and pulmonary embolism in a child with pneumonia due to Mycoplasma pneumoniae. J Natl Med Assoc 2009; 101: 956-958

9. Doğan M, Açıkgöz M, Bora A, Başaranoğlu M, Oner AF: Varicella associated purpura-fulminans and multiple deep vein thromboses: A case report. J Nippon Med Sch 2009; 76: 165-168

10. Kazanci E, Oguz KK, Gurgey A, Topçu M: Streptococcus oralis as a risk factor of middle cerebral artery thrombosis. $J$ Child Neurol 2005; 20: 611-613

11. WHO Pandemic (H1N1) 2009 update 78

12. Potter MN, Foot AB, Oakhill A: Influenza A and the virus associated haemophagocytic syndrome: Cluster of three cases in children with acute leukemia. J Clin Pathol 1991; 44: 297-299

13. Klein A, Corazza F, Demulder A, Van Beers D, Ferster A: Recurrent viral associated hemophagocytic syndrome in a child with Langerhans cell histiocytosis. J Pediatr Hematol Oncol 1999; 21: 554-556

14. Harms PW, Schmidt LA, Smith LB, Newton DW, Pletnewa MA, Walters LL, Tomlins SA, Fisher-Hubbard A, Napolitano LM, Park PK, Blalavas M, Fantone J, Myers JL, Jentzen JM: Autopsy findings in eight patients with fatal H1N1 infection. Am J Clin Pathol 2010; 134: 27-35

15. Visseren FL, Bouwman JJ, Bouter KP, Diepersloot RJ, de Groot PH, Erkelens DW: Procoagulant activity of endothelial cells after infection with respiratory viruses. Thromb Haemost 2000; 84: 319-324

16. Keller TT, van der Sluijs KF, de Kruif MD, Gerdes VE, Meijers JC, Florquin S, van der Poll T, van Gorp EC, Brandjes DP, Büller HR, Levi M: Effects on coagulation and fibrinolysis induced by influenza in mice with a reduced capacity to generate activated protein $C$ and a deficiency in plasminogen activator inhibitor type 1. Circ Res 2006; 99: 1261-1269

17. Zhu T, Carcaillon L, Martinez I, Cambou JP, Kyndt X, Guillot K, Vergnes MC, Scarabin PY, Emmerich P: Association of influenza vaccination with reduced risk of venous thromboembolism. Thromb Haemost 2009; 102: 1009-1101 